\title{
Quantification of Steroid Receptors Gene Expression in Breast Cancer Patients: Possible Correlation with Serum Level of Adipocytokines
}

\author{
Rana Jahanban Esfahlan ${ }^{1,2,3}$, Nosratollah Zarghami ${ }^{1,2^{*}}$, Mohammad Rahmati-Yamchi ${ }^{4}$, \\ Amir Monfaredan ${ }^{5}$, Samira Valiyari ${ }^{6}$, Ali Jahanban Esfahlan ${ }^{3,7}$, Raziallah Jafari Jozani ${ }^{8}$, \\ Morteza Gojazadeh ${ }^{9}$, Fereidoun Mamaghani ${ }^{1,4}$, Majid Mobasseri ${ }^{10}$
}

\begin{abstract}
${ }^{1}$ Drug Applied Research Center, Radio Pharmacy Lab, Tabriz, Iran; ${ }^{2}$ Department of Medical Biotechnology, Faculty of Advanced Medical Sciences, Tabriz University of Medical Sciences, Tabriz, Iran; ${ }^{3}$ Student Research Committee, Tabriz University of Medical Sciences, Tabriz, Iran; ${ }^{4}$ Department of Clinical Biochemistry, Faculty of Medicine, Tabriz University of Medical Sciences, Tabriz, Iran; ${ }^{5}$ Department of Hematology, Faculty of Medicine, Tabriz University of Medical Sciences, Tabriz, Iran; ${ }^{6}$ Department of Immunology, Faculty of Medicine, Tabriz University of Medical Sciences, Tabriz, Iran; ${ }^{7}$ Department of Pharmaceutical Biotechnology, Faculty of Pharmacy, Tabriz University of Medical Sciences, Tabriz, Iran; ${ }^{8}$ Department of Clinical Sciences, Faculty of Veterinary Medicine, University of Tabriz, Tabriz, Iran; ${ }^{9}$ Infectious and Tropical Disease Research Center, School of Medicine, Tabriz University of Medical Sciences, Tabriz, Iran; ${ }^{10}$ Department of Internal Medicine, Division of Endocrinology and Metabolic Disorders, Imam Reza Teaching Hospital, Tabriz University of Medical Sciences, Tabriz, Iran.

E-mail: ${ }^{*}$ zarghami@tbzmed.ac.ir
\end{abstract}

Received September $1^{\text {st }}, 2011$; revised October $9^{\text {th }}, 2011$; accepted November $20^{\text {th }}, 2011$.

\begin{abstract}
Background: While the role of adipocyte-derived hormones in breast cancer pathogenesis well studied, it is speculated that there is a crosstalk between adipocytokines and Esterogen receptor $(E R)$ signaling. To test this hypothesis we evaluate the possible correlation between serum levels of adipocytokins with steroid hormone receptors gene expression in breast cancer patients. Methods: In this case-control study, 70 women with breast cancer participated with different grades of obesity (36 none obese, $B M I<25 \mathrm{~kg} / \mathrm{m}^{2}$ and 34 obese, $B M I \geq 25 \mathrm{~kg} / \mathrm{m}^{2}$ ). Serum level of adiponectin, leptin, TNF $\alpha$ and IL6 determined by ELISA. Following quantitative expression of androgen receptor (AR), progesterone receptor $(P R)$ and estrogen receptors (ERa and ER $\beta)$ mRNA in tumor tissues evaluated by Real-time PCR. Results: We find a significant reverse correlation between serum level of Adiponectin and ER and PR $m R N A(r=-0.229, n=64, p$ $=0.035$ and $r=-0.220, n=64, p=0.041)$ but no correlation was between adiponectin and, ER $\beta$ and AR in samples $(P$ $>0.05)$. In case of leptin, we observed a positive correlation between leptin and ER and PR $m R N A$. $(r=0.553, n=64$, $p<0.001, r=0.359, n=64, p=0.002$ and a reverse significant correlation between leptin and ER $\beta(r=-0.506, n=64$ and $p<0.001)$. We also observed a significant correlation between TNF $\alpha$ and IL6 with steroid receptors gene expression in samples $(P<0.05)$. Conclusion: As the presence of steroid receptors are used as the most common prognostic markers in breast cancer patients, so targeting adipocytokines as potential regulators of steroid receptorsgene expression can be a new approach in treatment of obese breast cancer subjects.
\end{abstract}

Keywords: Obesity, Breast Cancer, Steroid Receptors, Adipocytokines

\section{Introduction}

Regarding that Obesity is a well-known risk factor for breast cancer [1], obese women are likely to have poor prognosis and metastatic breast cancer [2] when they are first diagnosed regardless of their menopausal status [3]. Although the exact mechanism remains to be determined [4], the hormonal changes associated with obesity are considered to be responsible for this relationship [5], with particular emphasis being placed on the increased production of estrogen [4]. Estrogens act on target cells through two receptors, esterogen receptor $\alpha(\mathrm{ER} \alpha)$ and esterogen receptor $(\mathrm{ER} \beta)$ [6].The actions of $\mathrm{ER} \alpha$ and $\mathrm{ER} \beta$ on gene transcription can be opposite; depending on cell context . Studies demonstrated that ER $\beta$ is not necessary for proliferation and that ER $\beta$ opposes the proliferative effects exerted by $\mathrm{ER} \alpha$ [7].The ratio of $\mathrm{ER} \alpha$ to $\mathrm{ER} \beta$ is a prognostic marker in breast tumors [8], such that 
$\mathrm{ER} \beta$ expression is indicative of more benign tumors [9], whereas ER $\alpha$ indicates malignant, aggressive tumors [10]. Beside ER gene expression, the role of other storied hormones such as Progesterone (PR) [11] and androgen Receptors (AR) in breast cancer development well studied [12]. Biochemical and immonohistochemical studies show that AR+ tumors are more frequent $(70 \%-90 \%)$ than $\mathrm{ER} \alpha+$ and $\mathrm{PR}+$ tumors $(60 \%-80 \%$ and $50 \%-70 \%$, respectively). Although ER $\alpha, \mathrm{PR}$ and $\mathrm{AR}$ are frequently co-expressed in breast tumors approximately $10 \%$ of $\mathrm{AR}+$ tumors and, perhaps more importantly, $25 \%$ of $\mathrm{AR}+$ tumors metastases can be negative for ER $\alpha$ and PR [13]. Despite the well-recognized relationship between obesity and estrogenic activity, it is evident that this cannot fully explain the association between adiposity and breast cancer risk [14]. Indeed, the adipose tissue is increasingly viewed as not only a fat-storing tissue but also an endocrine organ secreting various adipocytokines [15]. Subsequently, both experimental and epidemiological data suggest the possible role of adipocytokines in the regulation of carcinogenesis as another link between obesity and breast cancer [1]. Leptin is a adipocyte derived hormone and obesity is associated with high circulating levels of leptin [16]. In vitro, leptin stimulates proliferation of multiple types of preneoplastic and neoplastic cells [17]. Leptin also functions as an inflammatory cytokine and appears to influence immune function, possibly by triggering release of interleukin- 6 and other cytokines [16]. Adiponectin is an anti-inflammatory protein that is produced almost exclusively by mature adipocytes [18]. Plasma adiponectin concentrations are inversely correlated with the BMI [19]. A correlation between adiponectin and angiogenic adipokines suggests that adiponectin may be an effective suppressor of pathological neovascularization [16]. Many studies have shown that the clinical effects and biological actions of adiponectin are opposed of leptin [20]. Studies confirm a significant inverse correlation between serum adiponectin levels and poor-prognosis breast cancer [21]. The role of other adipocytokins such as tumor necrosis factor $(\mathrm{TNF} \alpha)$ and interlukin-6(IL6) is well recognized [22] and like as leptin, increased secretion of these adipocyte-derives hormones involve in breast cancer pathogenesis [23]. It is notable that these three adipocytokins can stimulate estrogen biosynthesis by the induction of aromatase activity [16]. As ER $\alpha$ is known to mediate tu- mour- promoting effects of 17-b estradiol [18], data suggest that adiponectin-triggered increase of ER $\beta$ isoform expression might be one important molecular mechanism underlying the protective effects of this adipocytokine [24].

Also the relation between obesity and adipocytokins well studied but there is no information about the possi- ble effect of steroid hormones on secretion of these adipocytokines in obese and none obese breast cancer subjects. So the aim of this study was to test the hypothesis that there is a correlation between steroid hormone receptors gene expression and serum level of ER regulated adipose tissue derived hormones in breast cancer patients with different grades of obesity.

\section{Materials and Methods}

\subsection{Patients and Samples (Tissue and Serum)}

This study was a discriptional — cross sectional study. All samples were obtained from 70 women who underwent biopsy or mastectomy surgical operation at Tabriz Emam Reza Hospital from July 2009 till May 2010. The whole project has been done in Tabriz Drug Applied Research Center. The samples were examined histologically for the presence of tumor cells by a Pathologist. The patients met the following criteria: primary unilateral non metastatic breast carcinoma for which complete clinical, histological and biological data were available; and no radiotherapy or chemotherapy before surgery.

\subsection{Adipocytocine Analysis (Plasma Leptin, Adiponectin, TNF $\alpha$ and IL6 Levels)}

Plasma concentrations of leptin and adiponectin were determined with the use of commercially available quantitative sandwich enzyme-linked immunosorbant assay (ELISA) kits (The mediagnost Leptin-ELISA E07 and Adiponectin-ELISA E09, Germany). The sensitivity of this assay was $0.2 \mathrm{ng} / \mathrm{ml}$ for leptin and $<0.6 \mathrm{ng} / \mathrm{ml}$ for adiponectin. Masked split specimens included within each batch were used to calculate the coefficient of variation (CV) within and between batches: the intra- and inter-assay CVs of leptin were below $10 \%$ for both and below $6.7 \%$ and $4.7 \%$ for adiponectin, respectively. The BMS223/4 and BMS223/4TEN human TNF- $\alpha$ ELISA and the BMS213/2 and BMS213/2TEN human IL-6 ELISA have prepared by Benser MedSystems is an enzyme-linked immunosorbent assay for the quantitative detection of human TNF- $\alpha$ and IL-6, respectively. The sensitivity of this assay was $2.3 \mathrm{pg} / \mathrm{ml}$ for TNF- $\alpha$ and $0.92 \mathrm{pg} / \mathrm{ml}$ for IL-6, respectively. Masked split specimens included within each batch were used to calculate the coefficient of variation $(\mathrm{CV})$ within and between batches: the intraand inter-assay CVs of TNF- $\alpha$ were below $3.2 \%$ and $10.3 \%$, and for IL-6 were $7.8 \%$ and $2.6 \%$, respectively.

\subsection{Preparation of Total RNA}

Approximately $100 \mathrm{mg}$ of tissue for RNA extraction by means of RNAX reagents previously described [25] .The quality of RNA samples was ensured by electrophoresis in an agarose gel followed by ethidium bromide staining, 
where the $18 \mathrm{~S}$ and $28 \mathrm{~S}$ RNA bands could be visualized under UV light. Quantification of RNA was performed in duplicate by spectrophometry at $260 \mathrm{~nm}$.

\section{4. cDNA Synthesis}

RNA was converted to cDNA after treating with DNase I. Reverse transcription of RNA was done in a final volume of $20 \mu \mathrm{l}$ by using of cDNA first strand synthesis kit (Fermentase) random hexamere and $1 \mu \mathrm{g}$ of total RNA. The samples were incubated at $65^{\circ} \mathrm{C}$ for $10 \mathrm{~min}$ and $42^{\circ} \mathrm{C}$ for $60 \mathrm{~min}$, and reverse transcriptase was inactivated by heating at $70^{\circ} \mathrm{C}$ for $5 \mathrm{~min}$ and cooling at $4^{\circ} \mathrm{C}$ for $5 \mathrm{~min}$.

\subsection{Real-Time RT- PCR}

Principle: Reactions are characterized by detection of cycling amplification of the PCR product, rather than the amount of PCR product accumulated after a fixed number of cycles. If the amount of the target molecule was larger, the earlier a significant increase in fluorescence is observed. The parameter $C t$ (threshold cycle) is defined as the cycle number at which the fluorescence generated by cleavage of the probe passes a fixed threshold above baseline. The $\triangle \triangle C T$ method used for determination of relative ERs gene expression, The $C t$ of each target gene compared to the $C t$ of its internal control (beta actin gene). Final results, expressed as $\mathrm{N}$-fold differences in tested gene expression (obese) relative to control gene (none obese), termed " $N$ fold changes" were determined as follows:

$$
N \text { fold changes }=2^{(\Delta C \text { test }-\Delta C t \text { control })}
$$

where $\Delta C t$ values of the sample and control are determined by subtracting the average $C t$ value of the target gene from the average $C t$ value of the beta actin gene. The qRT-PCR assay of steroid receptors in details have been described in our previous work [25]. Primer sequences for qRT-PCR summarized in Table 1.

\subsection{Statistical Analysis}

Differences between obese and non-obese groups in age at enrollment, age at menarche, age at menopause were tested using the chi-square test. In addition, Student's t-test was used to evaluate differences in categorical breast cancer risk factors between obese and non-obese. Pearson correlation coefficients were used to examine cross-sectional relationships between steroid hormone receptors expression and adipocytokines among subjects. All statistical analysis was conducted using SPSS statistical software (version 16). $\mathrm{P}$ values below the conventional level of statistical significance $(\mathrm{P}<0.05)$ were considered statistically significant.

\section{Results}

In this case-control study, 70 women with breast cancer participated with different grades of obesity (36 none obese, BMI $<25 \mathrm{~kg} / \mathrm{m}^{2}$ and 34 obese, BMI $\geq 25 \mathrm{~kg} / \mathrm{m}^{2}$ ). The mean age of Participants was $44.53 \pm 1.79 \mathrm{yr}$ (ranged from 21 - 70 years old). Patients with previous history of radiotherapy or chemotherapy Excluded from this study. The baseline characteristics are summarized in Table 2.

\subsection{Serum Level of Adipocytokins in Blood Samples}

We analyzed serum level of leptin, adiponectin, TNF $\alpha$ and IL6 in 70 breast cancer subjects. The mean serum level of adipocytokins summarized in Table 3 . The mean serum level of leptin, TNF $\alpha$ and IL6 were higher in obese cases $(\mathrm{P}=0.04$ and $\mathrm{P}=0.00$ and $\mathrm{P}=0.04$ respectively) while in contrast mean serum level of adiponectin was lower in obese ones $(P=0.011)$. As a result, there was a significant positive correlation between leptin and TNF $\alpha$ and IL6 with BMI $(\mathrm{r}=0.619, \mathrm{n}=64, \mathrm{P}<0.001$ and $\mathrm{r}=0.728, \mathrm{n}=64, \mathrm{P}=0.001$ and $\mathrm{r}=0.413, \mathrm{n}=64$ and $\mathrm{P}<0.001)$ and also there was a negative reverse correlation between adiponectin and BMI in breast cancer cases $(\mathrm{r}=-0.27, \mathrm{n}=64, \mathrm{P}=0.030)$. Spearman correlation show that there was a significant negative correlation between serum level of adiponectin and leptin $(\mathrm{r}=-0.29$, $\mathrm{n}=64, \mathrm{P}=0.017$ ). We find no correlation between serum level of adiponectin and other two adipocytokins $(\mathrm{P}>0.05)$ but we observed a positive significant correlation between leptin and TNF $\alpha$ and IL6 serum level $(\mathrm{r}=0.506, \mathrm{n}=64$, $\mathrm{P}<0.001$ and $\mathrm{r}=0.49, \mathrm{p}<0.001$ respectively).

Table 1. Primer sequences for RT-real Time PCR.

\begin{tabular}{clcc}
\hline $\boldsymbol{m} \boldsymbol{R} \boldsymbol{A}$ & \multicolumn{1}{c}{ Primer sequence } & Product size & source \\
\hline \multirow{2}{*}{$\boldsymbol{\alpha}$} & $\begin{array}{l}\text { TGA TGA AAG GTG GGA TAC GA } \\
\text { AAG GTT GGC AGC TCT CAT GT }\end{array}$ & $125 \mathrm{bp}$ & Pfeiler et al., 2007 [18] \\
\hline $\mathbf{E R \boldsymbol { \beta }}$ & $\begin{array}{l}\text { GCT TAG TGG AGC TCA GCC TG } \\
\text { AGGATCATGGCCTTGACACAGA }\end{array}$ & $262 \mathrm{bp}$ & Pffafl et al., 2001 [30] \\
\hline $\mathbf{P R}$ & $\begin{array}{l}\text { GAACCAGATGTGATCTATGCAGGA } \\
\text { CGAAAACCTGGCAATGATTTAGAC }\end{array}$ & $122 \mathrm{bp}$ & Cremoux et al., 2002 [11] \\
\hline AR & $\begin{array}{l}\text { CCTGGCTTCCGCAACTTACAC } \\
\text { GGACTTGTGCATGCGGTACTCA }\end{array}$ & $168 \mathrm{bp}$ & Bieche et al., 2001 [31] \\
\hline Beta actin & $\begin{array}{l}\text { TCCCTGGAGAAGAGCTACG } \\
\text { GTAGTTTCGTGGATGCCACA }\end{array}$ & $134 \mathrm{bp}$ & Genebank accession: NM_001101 \\
\hline
\end{tabular}


Table 2. Characteristics of obese and non-obese breast cancer patient.

\begin{tabular}{|c|c|c|c|}
\hline Baseline characteristics & None obese $(n=36)$ Mean \pm SE & Obese $(n=34)$ Mean \pm SE & $P$ value \\
\hline Age at enrollment (yrs) & $43.82 \pm 1.78$ & $45.42 \pm 2.27$ & 0.45 \\
\hline BMI (kg/m2) & $23.23 \pm 0.23$ & $29.80 \pm 0.63$ & 0.000 \\
\hline Family history of Breast cancer & No. $(\%)$ & No. $(\%)$ & \\
\hline Yes & $18(54.5)$ & $6(22.2)$ & \\
\hline No & $15(45.5)$ & $21(77.8)$ & 0.01 \\
\hline Family history of obesity & No. $(\%)$ & No. $(\%)$ & \\
\hline Yes & $23(69.7)$ & $22(81.5)$ & \\
\hline No & $10(30.3)$ & $5(18.5)$ & 0.22 \\
\hline \multicolumn{4}{|l|}{ Menopause status } \\
\hline Premenopausal & $21(63.6)$ & $12(46.2)$ & \\
\hline Postmenopausal & $12(36.4)$ & $14(53.8)$ & 0.14 \\
\hline \multicolumn{4}{|l|}{ Age at first live birth (yr) } \\
\hline $17>$ & $12(37.5)$ & $12(48.0)$ & \\
\hline $18-23$ & $11(34.4)$ & $10(40)$ & 0.32 \\
\hline $24<$ & $9(28.1)$ & $3(12)$ & \\
\hline \multicolumn{4}{|l|}{ Age at menarche(yr) } \\
\hline $12>$ & $10(30.3)$ & $6(23.1)$ & \\
\hline 13 & $5(15.2)$ & $10(38.5)$ & 0.12 \\
\hline $14<$ & $18(54.5)$ & $10(38.5)$ & \\
\hline
\end{tabular}

Table 3. Serum level of adipocytokines in obese and none obese breast cancer patients.

\begin{tabular}{cccc}
\hline Adipocytokine & None Obese $(\mathbf{n}=\mathbf{3 4})$ Mean $\pm \mathbf{S E}$ & Obese $(\mathbf{n}=\mathbf{3 6})$ Mean $\pm \mathbf{S E}$ & $\mathbf{p}$ \\
\hline Adiponectin(ng/ml) & $10.61 \pm 0.66$ & $8.33 \pm 0.48$ & 0.011 \\
Leptin(ng/ml) & $9.57 \pm 1.08$ & $31.68 \pm 4.49$ & 0.004 \\
$\mathbf{T N F} \boldsymbol{\alpha}(\mathbf{p g} / \mathbf{m l})$ & $3.53 \pm 0.12$ & $8.44 \pm 2.21$ & 0.000 \\
$\mathbf{I L 6}(\mathbf{p g} / \mathbf{m l})$ & $3.72 \pm 0.28$ & $7.17 \pm 0.62$ & 0.004 \\
\hline
\end{tabular}

\subsection{Correlation between Steroid Receptors and Serum Level of Adipocytokines in Breast Cancer Patients}

One tailed spearman coefficient test show that there was a significant reverse correlation between serum level of Adiponectin and $\mathrm{ER} \alpha$ and PR mRNA $(\mathrm{r}=-0.229, \mathrm{n}=64$, $\mathrm{P}=0.035$ and $\mathrm{r}=-0.220, \mathrm{n}=64, \mathrm{P}=0.041)$ but no correlation was between adiponectin and, ER $\beta$ and $\mathrm{AR}$ in samples $(\mathrm{P}>0.05)$. In case of leptin, we observed a positive correlation between leptin and $\mathrm{ER} \alpha$ and PR mRNA. $(\mathrm{r}=0.553, \mathrm{n}=64, \mathrm{P}<0.001, \mathrm{r}=0.359, \mathrm{n}=64, \mathrm{P}=0.002$ and a reverse significant correlation between leptin and $\mathrm{ER} \beta(\mathrm{r}=-0.506, \mathrm{n}=64$ and $\mathrm{P}<0.001)$. In case of $\mathrm{TNF} \alpha$, we observed a positive correlation between TNF $\alpha$ and ER $\alpha$ and PR mRNA. $(\mathrm{r}=0.497, \mathrm{n}=64, \mathrm{P}<0.001, \mathrm{r}$ $=0.361, \mathrm{n}=64, \mathrm{P}=0.002)$ and a reverse significant correlation between $\mathrm{TNF} \alpha$ and $\operatorname{ER} \beta(\mathrm{r}=-0.483, \mathrm{n}=64$ and 
$\mathrm{P}<0.001$ ). There was a positive correlation between IL6 and $\mathrm{ER} \alpha$ and PR mRNA. $(\mathrm{r}=0.371, \mathrm{n}=64, \mathrm{P}=0.001, \mathrm{r}$ $=0.227, \mathrm{n}=64, \mathrm{P}=0.036$ and a reverse significant correlation between IL6 and $\operatorname{ER} \beta(\mathrm{r}=-0.503, \mathrm{n}=64$ and $\mathrm{P}$ $<0.001)$. We find no correlation between AR mRNA and none of adipocytokine (see Table 4).

\section{Discussion}

Obesity has been associated with increased mortality from cancers of the colon, breast (in postmenopausal women) [5], endometrium, kidneys (renal cell), esophagus (adenocarcinoma), gastric cardia, pancreas, prostate, gallbladder, and liver [19]. The mechanisms and pathways involved in obesity-related carcinogenicity are multifaceted and difficult to extricate [1]. For example, increased energy intake, decreased energy output and increased adipose tissue mass could be causes of cancer [26]. Increased adipose tissue as a potential source of metabolic and endocrine modulators of oncogenic cascades will be cause cancer [3]. Studies have shown that the common denominators between obesity and cancer include Adipocyte derived hormones (leptin ,resistin, adiponectin, $\mathrm{TNF} \alpha$, IL-6, ․) neurochemicals; hormones such as insulin like growth factor 1 (IGF-1), insulin, leptin; sex steroids such as esterogen; adiposity; insulin resistance; and inflammation [19]. Like many other researcher our study indicate for the undeniable effects of adipocytokins in breast cancer [27], in our study there was a negative correlation between leptin, TNF $\alpha$ and IL6 and a reverse correlation between adiponectin and BMI as predicted. Also the connection between obesity and Adipocytokins well studied [1]; there is evidence show that secretion of some of these adipocytokins can affect pattern of estrogen receptors status [28]. Treeck et al. postulated that there is a crosstalk between adiponectin and ER signaling. In their study In MCF-10A cells, adiponectin triggered a significant increase of ER $\beta 2$ and ER $\beta 5$ mRNA levels [24]. $\mathrm{ER} \beta$ is the dominant estrogen receptor in normal breast tissue [10], but its expression declines during tumorigenesis, but at the other hand expression of ER $\alpha$ that can exert mitogenic effects - increases during tumorgenesis [29]. ER $\beta$ has anti mitogeneic activites and that regulate expression of $E R \alpha$ expression [6]. In our study we investigated only the total ER $\beta$ mRNA, while far now at least five isoforms for this esterogen receptor have been described and that the most anti mitigenic activites that can inhibit ER $\alpha$ expression through hetrodimerization can attributed to ER $\beta 2$ isoforms [10]. Maybe it's a reason that why our finding not confirmed findings of what treek and his collegues that there may be a possible synergic crosstalk between adiponectin and some ER $\beta$ isoforms. Also in our study we find no correlation between serum level of ER $\beta$ mRNA and adiponectin but those that have lower adiponectin exhibit a high expression of ER $\alpha$ and PR. Moreover we find a negative correlation between serum level of leptin and ER $\beta$. In case of two other bad adipocytokins like as TNF $\alpha$ and IL6 - the results was like as leptin. These three bad adipocyte derived hormones that their secretion increases during mammary tumorgenesis specially in obese subjects was in a close positive correlation with expression of bad steroid hormones (ER $\alpha$ and PR ) but in a reverse correlation with expression of ER $\beta$ that act as a tumor suppressor gene and in this case is comparable with adiponectin. While ER $\beta$ and adiponectin both have similar effects, they both exert anti tumor effects and decreased production of both is in relation with poor prognosis in breast cancer.

Table 4. Correlation between steroid hormone receptors mRNA and adipocytokines level.

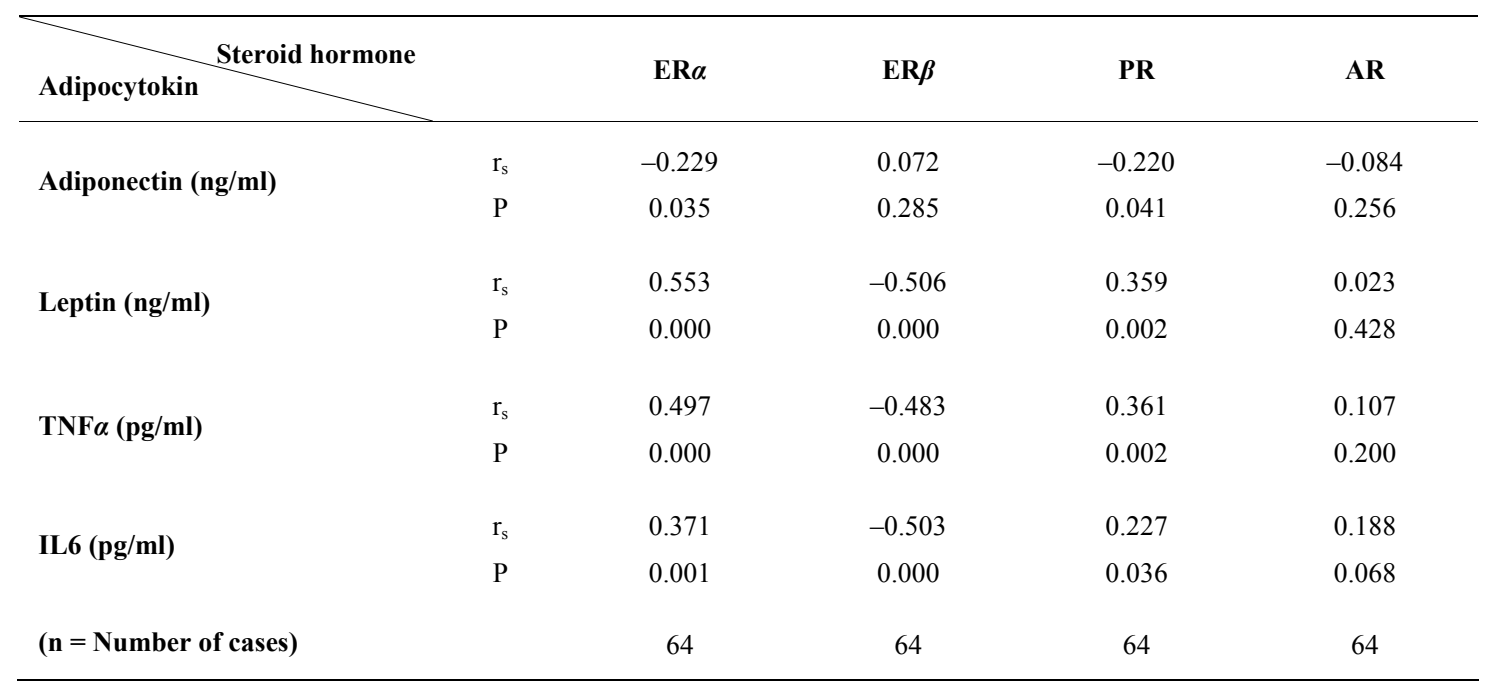




\section{Conclusions}

In brief, as the presence of steroid receptors are used as the most common prognostic value in breast cancer patients and adipocytokines can play a significant role in steroid hormone receptors gene expression so targeting and controlling the serum level of these adipocyte-derived hormones with emphasizing on losing weight can improve ER positiveness in obese subjects, while losing weight can decrease serum level of bad adipocytokins such as leptin and at the other hand increases the serum level of good adipocytokins such as adiponectin and this in turn may lead to achieving better prognosis and better response to endocrine therapy in obese breast cancer patients .

\section{Acknowledgements}

This work financially supported by Iranian National Science Foundation (INSF) with the ref code of 88000604 (Apri12/2010). We appreciate all individuals who participated in this study.

\section{REFERENCES}

[1] D. Housa, J. Housova, Z. Vernerova and M. Haluzik, "Adipocytokines and Cancer," Physiological Research, Vol. 55, No. 3, 2006, pp. 233-244.

[2] A. R. Carmichael, S. Bendall, L. Lockerbie, R. J. Prescott and T. Bates, "Does Obesity Compromise Survival in Women with Breast Cancer?" Breast, Vol. 13, No. 2, 2004, pp. 93-96. doi:10.1016/i.breast.2003.03.002

[3] S. Loi, R. L. Milne, M. L. Friedlander, M. R. McCredie, G. G. Giles, J. L. Hopper and K. A. Phillips, "Obesity and Outcomes in Premenopausal and Postmenopausal Breast Cancer," Cancer Epidemiology, Biomarkers and Prevention, Vol. 14, No. 7, 2005, pp. 1686-1691. doi:10.1158/1055-9965.EPI-05-0042

[4] A. R. Carmichael and T. Bates, "Obesity and Breast Cancer: A Review of the Literature," Breast, Vol. 13, No. 2, 2004, pp. 85-92. doi:10.1016/j.breast.2003.03.001

[5] A. R. Carmichael, "Obesity as a Risk Factor for Development and Poor Prognosis of Breast Cancer," An International Journal of Obstetrics and Gynaecology, Vol. 113, No. 10, 2006, pp. 1160-1166. doi:10.1111/j.1471-0528.2006.01021.x

[6] V. Speirs and R. A. Walker, "New Perspectives into the Biological and Clinical Relevance of Oestrogen Receptors in the Human Breast," Journal of Pathology, Vol. 211, 2007, pp. 499-506. doi:10.1002/path.2130

[7] G. P. Skliris, P. J. Carder, M. R. Lansdown and V. Speirs, "Immunohistochemical Detection of ERbeta in Breast Cancer: Towards More Detailed Receptor Profiling?" British Journal of Cancer, Vol. 84, No. 5, 2001, pp. 10951098. doi:10.1054/bjoc. 2001.1721

[8] R. Cullen, T. M. Maguire, E. W. McDermott, A. D. K.
Hill, N. J. O. Higgins and M. J. Duffy, "Studies on Oestrogen Receptor-a and -b mRNA in Breast Cancer," European Journal of Cancer, Vol. 37, No. 9, 2001, pp. 11181122.

[9] G. C. Markey, R. Cullen, P. Diggin, A. D. Hill, E. W. Mc Dermott, N. J. O’Higgins and M. J. Duffy, "Estrogen Receptor-Beta mRNA Is Associated with Adverse Outcome in Patients with Breast Cancer," Tumor Biology, Vol. 30, No. 4, 2009, pp. 171-175. doi:10.1159/000236409

[10] J. Matthews and J. A. Gustafsson, "Estrogen Signaling: A Subtle Balance between ER Alpha and ER Beta," Molecular Interventions, Vol. 3, No. 5, 2003, pp. 281-292. doi:10.1124/mi.3.5.281

[11] C. P. de, C. Tran-Perennou, C. Elie, E. Boudou, C. Barbaroux, M. F. Poupon, R. Y. De, B. Asselain and H. Magdelenat, "Quantitation of Estradiol Receptors Alpha and Beta and Progesterone Receptors in Human Breast Tumors by Real-Time Reverse Transcription-Polymerase Chain Reaction," Biochemical Pharmacology, Vol. 64, No. 3, 2002, pp. 507-515.

[12] I. Bieche, B. Parfait, S. Tozlu, R. Lidereau and M. Vidaud, "Quantitation of Androgen Receptor Gene Expression in Sporadic Breast Ttumors by Real-Time RT-PCR: Evidence that MYC Is an AR-Regulated Gene," Carcinogenesis, Vol. 22, No. 9, 2001, pp. 1521-1526. doi:10.1093/carcin/22.9.1521

[13] L. O. Gonzalez, M. D. Corte, J. Vazquez, S. Junquera, R. Sanchez, A. C. Alvarez, J. C. Rodriguez, M. L. Lamelas and F. J. Vizoso, "Androgen Receptor Expresion in Breast Cancer: Relationship with Clinicopathological Characteristics of the Tumors, Prognosis, and Expression of Metalloproteases and Their Inhibitors," BMC Cancer, Vol. 8, 2008, p. 149. doi:10.1186/1471-2407-8-149

[14] J. M. Holly and C. M. Perks, "Cancer as an Endocrine Problem," Best Practice and Research Clinical Endocrinology and Metabolism, Vol. 22, No. 4, 2008, pp. 539550. doi:10.1016/j.beem.2008.07.007

[15] W. K. Hou, Y. X. Xu, T. Yu, L. Zhang, W. W. Zhang, C. L. Fu, Y. Sun, Q. Wu and L. Chen, "Adipocytokines and Breast Cancer Risk," Chinese Medical Journal, Vol. 120, No. 18, 2007, pp. 1592-1596.

[16] M. Rahmati-Yamchi, N. Zarghami, M. Rahbani and A. Montazeri, "Plasma Leptin, hTERT Gene Expression, and Anthropometric Measures in Obese and Non-Obese Women with Breast Cancer," Breast Cancer, Vol. 5, 2011, pp. 27-35.

[17] M. Artac and K. Altundag, "Leptin and Breast Cancer: An Overview," Medical Oncology, 2011, pp. 1-8. doi:10.1007/s12032-011-0056-0

[18] G. H. Pfeiler, C. Buechler, M. Neumeier, A. Schaffler, G. Schmitz, O. Ortmann and O. Treeck, "Adiponectin Effects on Human Breast Cancer Cells Are Dependent on 17-Beta Estradiol," Oncology Reports, Vol. 19, No. 11, 2008, pp. 787-793.

[19] I. Kelesidis, T. Kelesidis and C. S. Mantzoros, "Adiponectin and Cancer: A Systematic Review," British Journal of Cancer, Vol. 94, 2006, No. 9, pp. 1221-1225. doi:10.1038/sj.bjc. 6603051 
[20] Y. J. Jeong, J. G. Bong, S. H. Park, J. H. Choi and H. K. Oh, "Expression of Leptin, Leptin Receptor, Adiponectin, and Adiponectin Receptor in Ductal Carcinoma in Situ and Invasive Breast Cancer," Journal of Breast Cancer, Vol. 14, No. 2, 2011, pp. 96-103. doi:10.4048/jbc.2011.14.2.96

[21] B. Sonmez, M. Seker, A. Bilici, E. F. Yavuz, B. B. Oven Ustaalioglu, M. Gumus, G. D. Ozturk, M. Karaduman, C. Gezen, M. Eser, N. Bildik and T. Salepci, "Is There Any Correlation among Adiponectin Levels in Serum, Tumor Tissue and Normal Tissue of the Same Patients with Breast Cancer?" Journal of Balkan Union of Oncology, Vol. 16, 2011, pp. 227-232.

[22] J. P. Bastard, M. Maachi, C. Lagathu, M. J. Kim, M. Caron, H. Vidal, J. Capeau and B. Feve, "Recent Advances in the Relationship between Obesity, Inflammation, and Insulin Resistance," European Cytokine Network, Vol. 17, No. 1, 2006, pp. 4-12.

[23] J. N. Fain, "Release of Interleukins and Other Inflammatory Cytokines by Human Adipose Tissue is Enhanced in Obesity and Primarily due to the Nonfat Cells," Journal of Vitamins and Hormones, Vol. 74, No. 6, 2006, pp. 443477.doi:10.1016/S0083-6729(06)74018-3

[24] O. Treeck, C. Lattrich, I. Juhasz-Boess, S. Buchholz, G. Pfeiler and O. Ortmann, "Adiponectin Differentially Affects Gene Expression in Human Mammary Epithelial and Breast Cancer Cells," British Journal of Cancer, Vol. 99, No. 8, 2008, pp. 1246-1250. doi:10.1038/sj.bjc.6604692

[25] R. Jahanban-Esfahlan, N. Zarghami, A. Jahanban-Esfahlan, M. Mollazadeh, K. Nejati and M. Nasiri, "The Possible Impact of Obesity on Androgen, Progesterone and Estrogen Receptors $(\mathrm{ER} \alpha$ and $\mathrm{ER} \beta)$ Gene Expression in
Breast Cancer Patients," Breast Cancer: Basic and Clinical Research, Vol. 5, 2011, pp. 227-237. doi:10.4137/BCBCR.S7707

[26] A. R. Carmichael, "Obesity and Prognosis of Breast Cancer," Obesity Research, Vol. 7, No. 4, 2006, pp. 333-340. doi:10.1111/j.1467-789X.2006.00261.X

[27] J. H. Kang, B. Y. Yu and D. S. Youn, "Relationship of Serum Adiponectin and Resistin Levels with Breast Cancer Risk," Journal of Korean Medical Science, Vol. 22, No. 1, 2007, pp. 117-121. doi:10.3346/jkms.2007.22.1.117

[28] D. Giuffrida, L. Lupo, G. A. La Porta, G. L. La Rosa, G. Padova, E. Foti, V. Marchese and A. Belfiore, "Relation between Steroid Receptor Status and Body Weight in Breast Cancer Patients," European Journal of Cancer, Vol. 28, No. 1, 1992, pp. 112-115. doi:10.1016/0959-8049(92)90397-K

[29] C. Zhao, K. Hlman-Wright and J. A. Gustafsson, "Estrogen Receptor Beta: An Overview and Update," Nuclear Receptor Signaling, Vol. 6, 2008, p. e003.

[30] M. W. Pfaffl, I. G. Lange, A. Daxenberger and H. H. Meyer, "Tissue-Specific Expression Pattern of Estrogen Receptors (ER): Quantification of ER Alpha and ER Beta mRNA with Real-Time RT-PCR," Acta Pathologica, Microbiologica et Immunologica Scandinavica, Vol. 109, 2001, pp. 345-355. doi:10.1034/j.1600-0463.2001.090503.x

[31] I. Bieche, B. Parfait, I. Laurendeau, I. Girault, M. Vidaud and R. Lidereau, "Quantification of Estrogen Receptor Alpha and Beta Expression in Sporadic Breast Cancer," Oncogene, Vol. 20, No. 56, 2001, pp. 8109-8115. doi:10.1038/sj.onc. 1204917 